\title{
Solar-thermal Water Splitting Using the Sodium Manganese Oxide Process \& Preliminary H2A Analysis
}

Todd M. Francis, Paul R. Lichty, Christopher Perkins, Melinda Tucker, Peter B. Kreider, Hans H. Funke, Allan Lewandowski, and Alan W. Weimer

University of Colorado

Boulder, C0 80309-0424

Final Report: DE-FG36-05G015044

\begin{abstract}
There are three primary reactions in the sodium manganese oxide high temperature water splitting cycle. In the first reaction, $\mathrm{Mn} 2 \mathrm{O} 3$ is decomposed to $\mathrm{MnO}$ at 1,500 ${ }^{\circ} \mathrm{C}$ and $50 \mathrm{psig}$. This reaction occurs in a high temperature solar reactor and has a heat of reaction of $173,212 \mathrm{~J} / \mathrm{mol}$. Hydrogen is produced in the next step of this cycle. This step occurs at $700^{\circ} \mathrm{C}$ and $1 \mathrm{~atm}$ in the presence of sodium hydroxide. Finally, water is added in the hydrolysis step, which removes $\mathrm{NaOH}$ and regenerates the original reactant, $\mathrm{Mn} 2 \mathrm{O}$.

The high temperature solar-driven step for decomposing Mn203 to MnO can be carried out to high conversion without major complication in an inert environment. The second step to produce $\mathrm{H} 2$ in the presence of sodium hydroxide is also straightforward and can be completed. The third step, the low temperature step to recover the sodium hydroxide is the most difficult. The amount of energy required to essentially distill water to recover sodium hydroxide is prohibitive and too costly. Methods must be found for lower cost recovery.

This report provides information on the use of $\mathrm{ZnO}$ as an additive to improve the recovery of sodium hydroxide. All other work resulting from project support has been published in peer-reviewed research journals as cited in the report and that information is not repeated here. Readers are referred to that disseminated information.
\end{abstract}




\section{Introduction}

The manganese oxide high temperature water splitting cycle has three reactions. In the first reaction, $\mathrm{Mn} 2 \mathrm{O} 3$ is decomposed to $\mathrm{MnO}$ at $1,500^{\circ} \mathrm{C}$ and $50 \mathrm{psig}$. This reaction occurs in a high temperature solar reactor and has a heat of reaction of 173,212 J/mol. Hydrogen is produced in the next step of this cycle. This step occurs at $700^{\circ} \mathrm{C}$ and $1 \mathrm{~atm}$ in the presence of sodium hydroxide. Finally, water is added in the hydrolysis step, which removes $\mathrm{NaOH}$ and regenerates the original reactant, $\mathrm{Mn2O}$. The reactions are shown below.

$$
\begin{array}{ll}
\text { Reaction } 1 \text { Decomposition: } & \mathrm{Mn}_{2} \mathrm{O}_{3} \rightarrow 2 \mathrm{MnO}+1 / 2 \mathrm{O}_{2} \\
\text { Reaction } 2 \mathrm{H}_{2} \text { Production: } & 2 \mathrm{MnO}+2 \mathrm{NaOH} \rightarrow 2 \mathrm{NaMnO}_{2}+\mathrm{H}_{2} \\
\text { Reaction } 3 \text { Hydrolysis: } & 2 \mathrm{NaMnO}_{2}+\mathrm{H}_{2} \mathrm{O} \rightarrow \mathrm{Mn}_{2} \mathrm{O}_{3}+2 \mathrm{NaOH}
\end{array}
$$

Previous experimental work is summarized in a number of publications. The published papers are summarized below with the reprinted abstracts:

Francis, T.M., C.J. Gump and A.W. Weimer, "Spinning wheel powder feeding device fundamentals and applications," Powder Technology, 170, 36-40 (2006).

Abstract - A spinning wheel powder feeding system has been developed as a conveying mechanism to feed fine particle aggregates on a laboratory scale. An example of a use of this conveying mechanism is with a transport tube reactor, since the reactor only provides a few seconds residence time to react the powder. Methods to shear the powder mechanically, as opposed to using a high gas velocity, are developed as to not reduce the available residence time in the reactor. The objective is to feed a powder at the smallest particle aggregate size possible rather than a large particle aggregate size generated by an upstream feeding device, and to achieve such dispersion using minimized gas flow. Statistical results show that the spinning wheel alone is able to reduce the mean aggregate size of the Particle Size Distribution (PSD) and when a minimal amount of gas is added to the system the PSD is reduced further. In addition, a fundamental model employing a discrete particle aggregate breakage equation combined with a Monte Carlo method has shown that the spinning wheel feeding system is able to consistently reduce particle aggregate size.

Francis, T.M., P.R. Lichty, and A.W. Weimer, "Manganese oxide dissociation kinetics for the Mn2O3 thermochemical water-splitting cycle. Part1:Experimental," Chemical Engineering Science, 65, 3709 (2010). 
Abstract - It is shown that the dissociation of $\mathrm{Mn} 2 \mathrm{O} 3$ to $\mathrm{MnO}$ in a short residence time aerosol flow reactor can achieve high conversions approaching $75 \%$ when the concentration of oxygen is kept below $0.25 \%$. Significant recombination reaction occurs when the oxygen content exceeds $0.25 \%$ by volume. Acual reaction mechanism for $\mathrm{Mn} 2 \mathrm{O} 3$ dissociation was found. High levels of dissociation are achievable when the reaction is carried out in an inert gas environment using a reactor configuration that limits the reverse reaction.

Francis, T.M., C. Perkins and A.W. Weimer, "Manganese oxide dissociation kinetics for the Mn2O3 thermochemical water-splitting cycle. Part2: CFD model," Chemical Engineering Science, 65, 4397-4410 (2010).

Abstract - A detailed CFD model was developed to better understand the kinetics and transport characteristics of $\mathrm{Mn} 2 \mathrm{O} 3$ dissociation in an aerosol flow reactor(AFR). Radiation was the dominant mode of heat transfer and a relation for radiation from the walls and attenuating volume to any volume element in the reactor was developed. Results compared favorably to what was observed experimentally and showed that solid feed concentration into a high temperature AFR has a significant effect on conversion. If the concentration becomes too high, simply increasing the temperature of the reactor wall will not provide enough energy to drive the reaction to a high conversion.

Additionally, the model showed that the bulk gas rate does not have that much effect on conversion in the AFR. This is important as a higher gas flowrate provides a faster quench, limiting the possibility of a recombination reaction. Finally, a case study for the diameter of the reactor tube showed that a higher conversion could be achieved by decreasing the size of the reactor tube. Multiple reaction tubes of smaller diameter are likely needed for scale-up.

Kreider, P.B., H.H. Funke, K. Cuche, M. Schmidt, A. Steinfeld, and A.W. Weimer, "Manganese oxide based thermochemical hydrogen production cycle," International Journal of Hydrogen Energy, 36, 7028-7037 (2011).

Abstract - $\mathrm{A} \mathrm{MnO} / \mathrm{NaOH}$ based three-step thermochemical water splitting cycle was modified to improve the hydrolysis of a-NaMnO2 (sodium manganate) and to recover $\mathrm{Mn}(\mathrm{III})$ oxides for the high-temperature reduction step. Sodium manganate forms in the reaction of $\mathrm{NaOH}$ with $\mathrm{MnO}$ that releases hydrogen. The hydrolysis of a$\mathrm{NaMnO} 2$ to manganese oxides and $\mathrm{NaOH}$ is incomplete even with a large excess of water and more than $10 \%$ sodium cannot be removed prior to the high-temperature reduction step. When mixed oxides of manganese with iron were used in the cycle, the $\mathrm{NaOH}$ recovery in the hydrolysis step improved from about $10 \%$ to $35 \%$ at $\mathrm{NaOH}$ concentrations above $1 \mathrm{M}$. Only $60 \%$ sodium was removed at $0.5 \mathrm{M}$ from the mixed oxides whereas more than $80 \%$ can be recovered at the same $\mathrm{NaOH}$ concentration when only manganese oxides are used. 10:1 Mn/Fe sample was cycled through all steps three times to confirm that multiple cycles are possible. The high-temperature reduction was carried out for $5 \mathrm{~h}$ at $1773 \mathrm{~K}$ under vacuum and the conversion was about 
$65 \%$ after the 3rd cycle. Since sodium carryover into the high-temperature reduction cannot be avoided, even with the energy intensive hydrolysis step, a modified two-step cycle without low temperature sodium recovery is proposed where a- $\mathrm{NaMnO} 2$ is reduced directly to $\mathrm{MnO}$ at $1773 \mathrm{~K}$ under vacuum. On a laboratory scale, about $60 \%$ of the sodium that volatilized at the high temperatures was trapped with a water-cooled cold finger and conversions were stable at about 35\% after three completed cycles.

There is difficulty separating sodium hydroxide from manganese in the hydrolysis step of this cycle. Therefore, zinc oxide, $\mathrm{ZnO}$, has been investigated as an additive to manganese to help increase the conversion of reaction 3 .

$$
\begin{array}{ll}
\text { Reaction } 1 \text { Decomposition: } & \mathrm{ZnMn}_{2} \mathrm{O}_{4} \rightarrow \mathrm{ZnMn}_{2} \mathrm{O}_{3}+1 / 2 \mathrm{O}_{2} \\
\text { Reaction } 2 \mathrm{H}_{2} \text { Production: } & \mathrm{ZnMn}_{2} \mathrm{O}_{3}+2 \mathrm{NaOH} \rightarrow \mathrm{Na}_{2} \mathrm{ZnMn}_{2} \mathrm{O}_{5}+\mathrm{H}_{2} \\
\text { Reaction } 3 \text { Hydrolysis: } & \mathrm{Na}_{2} \mathrm{ZnMn}_{2} \mathrm{O}_{5}+\mathrm{H}_{2} \mathrm{O} \rightarrow \mathrm{ZnMn}_{2} \mathrm{O}_{4}+2 \mathrm{NaOH}
\end{array}
$$




\section{Process Design and Economics}

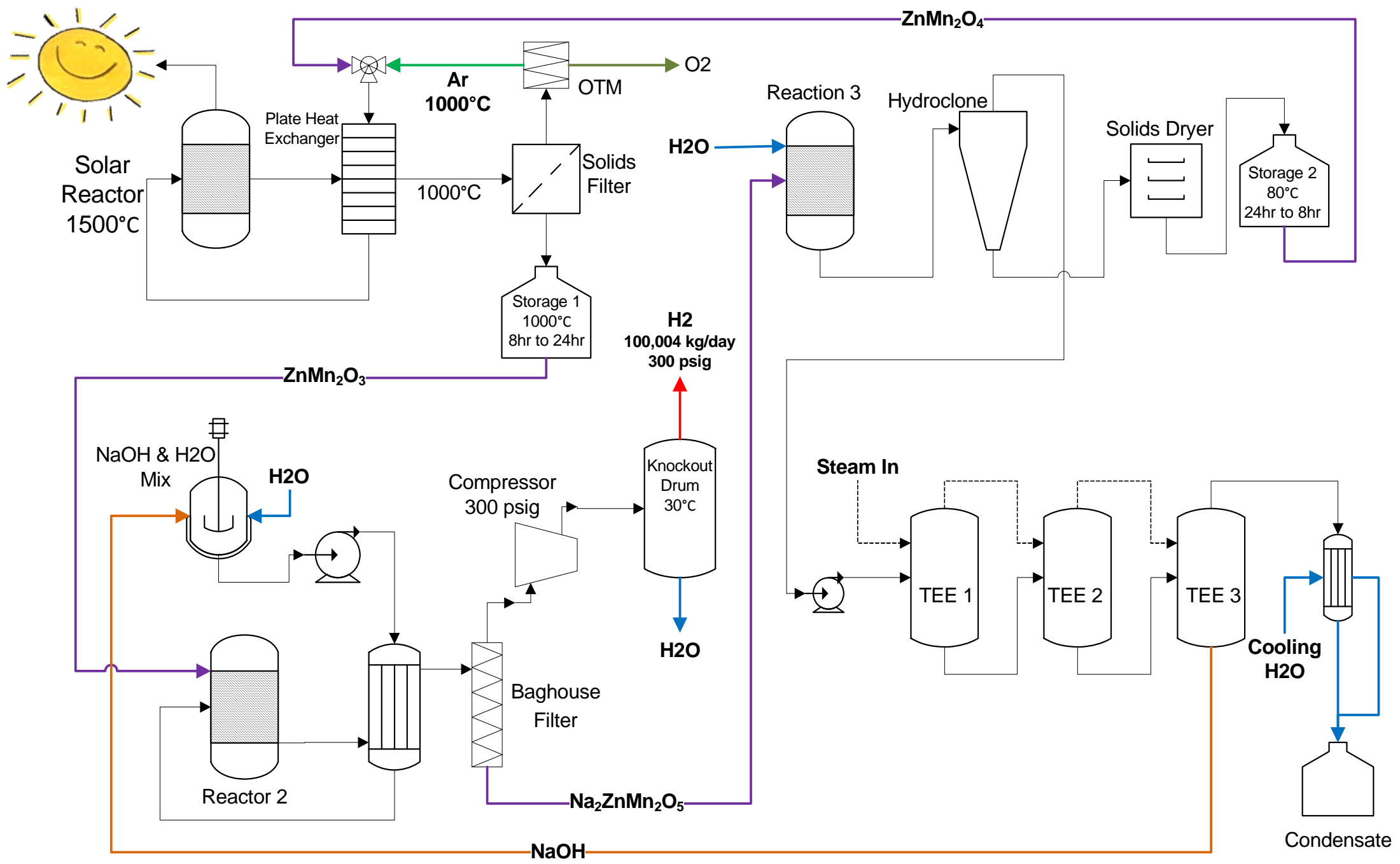




\section{A. Capital Equipment Design \& Costing}

Screw conveyors are used to transport the $\mathrm{ZnMn}_{2} \mathrm{O}_{4}$ from the chemical plant up to the solar reactor. The conveyors have a maximum length of 37 meters while the 6 towers are 239 meters tall. A total of 36 conveyors are need for this plant for a total capital investment of \$2MM.

The conveyors feed hoppers at the top of the solar towers. There is one hopper per tower with a holding time of 90 minutes and a total cost of $\$ 172 \mathrm{k}$.

Star valve rotary feeders move the $\mathrm{ZnMn}_{2} \mathrm{O}_{4}$ from the hopper into the solar reactor and are also used to move the reduction products out of the solar reactors. Two valves per reactor or twelve valves total cost $\$ 129 \mathrm{k}$.

$\mathrm{ZnMn}_{2} \mathrm{O}_{4}$ is preheated in a titanium flat plate heat exchanger by the reduction product sensible heat. Each heat exchanger has a surface area of $711 \mathrm{~m}^{2}$ and the total cost is $\$ 3 \mathrm{MM}$.

The solar reactors have a residence time of 30 seconds. They are 20 foot vertical vessels with four 12 inch silicon carbide reaction tubes. The total capital cost of 6 solar reactors is $\$ 2.5 \mathrm{MM}$.

Argon is used to fluidize the $\mathrm{ZnMn}_{2} \mathrm{O}_{4}$ feed. Oxygen produced in the decomposition reaction is mixed with the argon feed in the decomposition reaction. An oxygen transport membrane is used to separate $\mathrm{O}_{2}$ from $\mathrm{Ar}$ downstream from the solar reactor. The membranes are 26.5 meters tall with a diameter of 8.8 meters and cost \$7MM.

Large volume field erected stainless steel storage tanks are used to store $\mathrm{ZnMn}_{2} \mathrm{O}_{3}$ at the base of each tower. The tanks have a holding capacity of 33.5 hours and will cost $\$ 4.8 \mathrm{MM}$.

Sodium hydroxide is mixed with water in a stainless steel agitated mixed tank. The total capital investment for 6 mixing tanks is \$262k.

The sodium hydroxide mixture is fed to the second reactor along with the $\mathrm{ZnMn}_{2} \mathrm{O}_{3}$ from the storage tank. The second reactor is a jacketed, stirred tank, 316 stainless steel, vertical vessel operating at $700^{\circ} \mathrm{C}$ and $1 \mathrm{~atm}$. The reactors cost $\$ 27.5 \mathrm{MM}$.

Two heat exchangers follow the second reactor and are used to remove heat from the hydrogen production products by preheating the $\mathrm{NaOH}$ solution feed 
into the second reactor. These heat exchangers are stainless steel floating head with 0.019 meter outside diameter tubes that have a 0.025 meter square pitch and a total heat exchange area of $209 \mathrm{~m}^{2}$. The heat exchangers cost $\$ 386 \mathrm{k}$.

A carbon steel baghouse filter follows the $\mathrm{NaOH}$ heat exchanger. The filter will separate solids from the hydrogen/water product stream. The filters cost $\$ 376 \mathrm{k}$.

Hydrogen is produced at $14.7 \mathrm{psig}$ in the second reactor and is then compressed to 318.4 psig before entering the pipeline. The system has a compression factor of 2.85 and has intercoolers with a pressure drop of 2 psig. The table below shows the resulting inlet and outlet pressures from each compression stage.

\begin{tabular}{|ccc|}
\hline Stage \# & Pin (psig) & Pout (psig) \\
\hline 1 & 14.7 & 41.9 \\
2 & 39.9 & 113.7 \\
3 & 111.7 & 318.4 \\
\hline
\end{tabular}

The compression system cost was determined using the Department of Energy's H2A Delivery Components Model v2.0. There is one compression system per tower and 3 compressors will be installed while only 2 will be operating at any time. The total installed cost for the compressors is $\$ 48 \mathrm{MM}$.

After compressing the hydrogen and water vapor, a knockout drum is used to drop the gas temperature down to $50^{\circ} \mathrm{C}$. Under the conditions the water is liquid, drops out the bottom, and the hydrogen has a composition of $99 \%$. The knockout drums are $\$ 3 M M$.

Reactor 3 is a stirred, glass lined, steel, vertical vessel with a volume of $54 \mathrm{~m}^{3}$ operating at $80^{\circ} \mathrm{C}$ and $1 \mathrm{~atm}$ with a total cost of $\$ 2.4 \mathrm{MM}$.

A hydroclone follows reactor 3 to separate $\mathrm{ZnMn}_{2} \mathrm{O}_{4}$ from the $\mathrm{NaOH} /$ water mixture. The hydroclones have a maximum flowrate of 1,200 gallons per minute. There will be three hydroclones per tower for a total of $\$ 358 \mathrm{k}$.

Water is removed from $\mathrm{ZnMn}_{2} \mathrm{O}_{4}$ using a rotary vacuum dryer with indirect flue gas and a drying time of 10 minutes. The dryers cost $\$ 1.1 \mathrm{MM}$.

After drying the $\mathrm{ZnMn}_{2} \mathrm{O}_{4}$ flows into small volume, field erected, 316 stainless steel, flat bottom, storage tanks. With a holding capacity of 36 hours the tanks have a total capital investment of $\$ 2.2 \mathrm{MM}$.

Finally, the $\mathrm{NaOH}$ /water mixture must be separated by a triple effect evaporator (TEE). The mixture is fed into the system using a 316 stainless steel centrifugal 
pump costing $\$ 22 \mathrm{k}$. The feed moves from the pump into the 316 stainless steel, vertical, jacketed tank evaporators. The breakdown of evaporator heat transfer area to cost is shown in the table below.

\begin{tabular}{|cc|}
\hline HE Area $\left(\mathbf{m}^{2}\right)$ & $\mathbf{T}_{\mathrm{Cl}}$ \\
\hline 790 & $\$ 2.6 \mathrm{MM}$ \\
9 & $\$ 237 \mathrm{k}$ \\
0.55 & $\$ 52 \mathrm{k}$ \\
\hline
\end{tabular}

There is a heat exchanger following the TEE which is used to cool the vapor leaving evaporator 3 . This is a carbon steel U-tube heat exchanger with 0.0254 meter square tube having a pitch $0.0254 \mathrm{~m}^{2}$ and a heat transfer area of $420 \mathrm{~m}^{2}$. These heat exchangers cost $\$ 81 \mathrm{k}$. A condensate tank collects the condensed water from the jacket of each evaporator has a diameter of 13 meters. The condensed water is recirculated through the cycle. The condensate tanks cost $\$ 52 \mathrm{k}$. The 6 complete TEE systems cost a total of \$7.5MM.

The following table shows the resulting total installed capital equipment cost.

\begin{tabular}{|lcrr|}
\hline Equipment & Installation Cost Factor & & \multicolumn{1}{c|}{$\mathbf{T}_{\mathrm{Cl}}$} \\
\hline Conveyors & 1.61 & $\$$ & $3,228,291$ \\
Hoppers & 2.3 & $\$$ & 396,154 \\
Screw Feeders & 2.3 & $\$$ & 295,972 \\
Heat Exchangers & 3.17 & $\$$ & $11,030,185$ \\
Solar Reactors & 3.17 & $\$$ & $7,856,262$ \\
Oxygen Transport Membrane & 2.32 & $\$$ & $16,179,494$ \\
Storage Tanks & 1.86 & $\$$ & $12,968,237$ \\
Agitated Mixers & 2.3 & $\$$ & 602,462 \\
Reactor 2 & 4.16 & $\$$ & $114,474,538$ \\
Baghouse Filters & 2.32 & $\$$ & 872,466 \\
Compression Systems & 2.15 & $\$$ & $102,909,486$ \\
Knockout Drums & 4.16 & $\$$ & $12,562,546$ \\
Reactor 3 & 4.16 & $\$$ & $9,903,331$ \\
Hydroclones & 1.73 & $\$$ & 619,988 \\
Dryers & 2.06 & $\$$ & $2,287,003$ \\
TEE & 1 & $\$$ & $7,502,881$ \\
Argon & 1 & $\$$ & 843,045 \\
Mn2O3 & 1 & $\$$ & $15,498,560$ \\
ZnO & 1 & $\$$ & $22,828,634$ \\
NaOH & 1 & $\mathbf{5 7 3 , 1 3 8 , 5 0 9}$ \\
\hline & & & $230,278,976$ \\
\hline
\end{tabular}




\section{Solar Field Design}

Solar heliostat and tower design in Daggett, CA with a production rate of $133,000 \mathrm{~kg} \mathrm{H} 2$ per 8 hour day.

\section{A. Solar Heat Input}

Reduction heat of reaction required to produce $133,000 \mathrm{~kg} \mathrm{H} 2 /$ day:

$$
\begin{aligned}
& \left(133,000 \frac{\mathrm{kg} \mathrm{H} 2}{\text { day }}\right)\left(\frac{\mathrm{molH} 2}{2.01588 \mathrm{~g}}\right)\left(\frac{1 \mathrm{~mol} \mathrm{Mn2O3}}{1 \text { molH2}}\right)\left(\frac{1,000 \mathrm{~g}}{\mathrm{~kg}}\right)(80 \% \text { conversion }) \\
& =8.25 E 7 \frac{\operatorname{molMn} 203}{\text { day }} \\
& \left(8.25 E 7 \frac{\mathrm{mol} \mathrm{ZnMn2O4}}{\text { day }}\right)\left(173,212 \frac{\mathrm{J}}{\mathrm{mol}}\right)=1.43 E 12 \frac{\mathrm{J}}{\mathrm{day}} \\
& \left(1.43 E 12 \frac{J}{d a y}\right)\left(\frac{h r}{3600 s}\right)\left(\frac{G W}{10^{9} * \frac{J}{S}}\right)=3.97 \frac{G W h r}{d a y} \\
& \left(3.97 \frac{G W h r}{d a y}\right)\left(365 \frac{d a y}{y r}\right)=\mathbf{1}, \mathbf{4 4 9} \frac{\boldsymbol{G W h r}}{\boldsymbol{y r}}
\end{aligned}
$$

Sensible heat input required to heat $\mathrm{Mn2O} 3, \mathrm{ZnO}$, and argon from the preheated temperature of $1,164 \mathrm{~K}$ to the reaction temperature of $1,500 \mathrm{~K}$ :

Mn2O3 sensible heat required:

$$
\begin{aligned}
& \left(8.25 E 7 \frac{\mathrm{mol} \mathrm{Mn2O3}}{\text { day }}\right)\left(138.606 \frac{\mathrm{J}}{\mathrm{mol} * K}\right)(1,773-1,164) K=6.96 E 12 \frac{\mathrm{J}}{\mathrm{day}} \\
& \left(6.96 E 12 \frac{\mathrm{J}}{\text { day }}\right)\left(\frac{\mathrm{hr}}{3600 \mathrm{~s}}\right)\left(\frac{G W}{10^{9} * \frac{J}{S}}\right)=1.93 \frac{G W h r}{d a y} \\
& \left(1.93 \frac{G W h r}{\text { day }}\right)\left(365 \frac{\text { day }}{y r}\right)=\mathbf{7 0 6} \frac{\boldsymbol{G W h r}}{\boldsymbol{y r}}
\end{aligned}
$$

$\mathrm{ZnO}$ sensible heat required:

$$
\begin{gathered}
\left(8.25 E 7 \frac{\mathrm{mol} \mathrm{Mn} 203}{\text { day }}\right)\left(\frac{1 \mathrm{molZnO}}{1 \mathrm{molMn} 203}\right)\left(24.47 \frac{\mathrm{J}}{\mathrm{mol} * \mathrm{~K}}\right)(1,773-1,164) \mathrm{K} \\
=1.28 E 12 \frac{\mathrm{J}}{\text { day }} \\
\left(1.28 E 12 \frac{\mathrm{J}}{\text { day }}\right)\left(\frac{\mathrm{hr}}{3600 \mathrm{~s}}\right)\left(\frac{G W}{10^{9} * \frac{J}{S}}\right)=0.36 \frac{G W h r}{d a y}
\end{gathered}
$$




$$
\left(0.36 \frac{G W h r}{d a y}\right)\left(365 \frac{d a y}{y r}\right)=\mathbf{1 3 0} \frac{\boldsymbol{G W h r}}{\boldsymbol{y r}}
$$

Ar sensible heat required:

$$
\begin{aligned}
& \left(8.25 E 7 \frac{\mathrm{mol} \mathrm{Mn2O3}}{\text { day }}\right)\left(\frac{3 \mathrm{molAr}}{1 \mathrm{molMn2O3}}\right)\left(20.786 \frac{\mathrm{J}}{\mathrm{mol} * \mathrm{~K}}\right)(1,773-1,164) \mathrm{K} \\
& =3.13 E 12 \frac{\mathrm{J}}{\mathrm{day}} \\
& \left(3.13 E 12 \frac{J}{d a y}\right)\left(\frac{h r}{3600 s}\right)\left(\frac{G W}{10^{9} * \frac{J}{S}}\right)=0.87 \frac{G W h r}{d a y} \\
& \left(0.87 \frac{G W h r}{d a y}\right)\left(365 \frac{d a y}{y r}\right)=317 \frac{G W h r}{y r}
\end{aligned}
$$

\section{Total Solar Heat Input}

$$
(1,449+706+130+317) \frac{G W h r}{y r}=\mathbf{2 , 6 0 2} \frac{\boldsymbol{G W h r}}{\boldsymbol{y r}}
$$

The solar field design is determined using Allan Lewandowski's Soltrace program.

\section{B. Heliostat Field and Towers}

(6) 239 meter tall towers are required to produce 2,602 GWhr/yr.

Each receiver has 3 heliostat fields with 74.5 acres of land per field and an efficiency of $65.8 \%$. Each field requires (934) $143 \mathrm{~m} 2$ heliostats for a total area of $133,378 \mathrm{~m} 2 /$ field, which will supply $87.423 \mathrm{MW} /$ field.

The entire plant will require $2.4 \mathrm{E} 6 \mathrm{~m} 2$ of heliostats with a total land area of 1,342 acres.

The parasitic electrical requirement is $0.20 \mathrm{~W} / \mathrm{m} 2$ or

$$
\begin{aligned}
& \left(0.20 \frac{W}{m^{2}}\right)\left(2.4 E 6 m^{2}\right)\left(\frac{M W}{10^{6} W}\right)=0.48 M W \\
& (0.48 M W)\left(8 \frac{h r}{d a y}\right)=3.84 \frac{M W h r}{d a y} \\
& \left(3.84 \frac{M W h r}{\text { day }}\right)\left(\frac{G W}{1,000 M W}\right)\left(365 \frac{d a y}{y r}\right)=\mathbf{1 . 4 0} \frac{\boldsymbol{G W h r}}{\boldsymbol{y r}}
\end{aligned}
$$




\section{Secondary Concentrators}

Each CPC has a surface area of $169 \mathrm{~m} 2$ with an efficiency of $91.5 \%$ and a concentration of 3,868 suns. There are 3 CPCs per receiver with a total area of $506.1 \mathrm{~m} 2$.

Of the 87.423 MW delivered to the CPC from one field, 79.997 MW is delivered to the receiver from one field. $240 \mathrm{MW}$ is supplied to each receiver by the 3 concentrators.

The overall annual efficiency is $40.2 \%$. 


\section{Reduction Product Heat Recovery}

Sensible heat recovered from cooling the reduction products from $1,500^{\circ} \mathrm{C}$ to $900^{\circ} \mathrm{C}$ will be used to preheat the solar reactor feed from $727^{\circ}$ to $890^{\circ} \mathrm{C}$.

$\mathrm{Mn} 2 \mathrm{O} 3$ sensible heat recovered:

$\left(8.25 E 7 \frac{\mathrm{mol} \mathrm{Mn2O3}}{\text { day }}\right)\left(138.606 \frac{\mathrm{J}}{\mathrm{mol} * \mathrm{~K}}\right)(1,773-1,174) K(20 \%$ unreacted $)$

$$
=1.37 E 12 \frac{\mathrm{J}}{\mathrm{day}}
$$

$\left(1.37 E 12 \frac{J}{d a y}\right)\left(\frac{h r}{3600 s}\right)\left(\frac{G W}{10^{9} * \frac{J}{S}}\right)=0.38 \frac{G W h r}{d a y}$

$\left(0.38 \frac{G W h r}{d a y}\right)\left(365 \frac{d a y}{y r}\right)=139 \frac{\boldsymbol{G W h r}}{\boldsymbol{y r}}$

ZnO sensible heat recovered:

$$
\begin{aligned}
& \left(8.25 E 7 \frac{\mathrm{mol} \mathrm{Mn2O3}}{\text { day }}\right)\left(\frac{1 \mathrm{molZnO}}{1 \mathrm{molMn} 203}\right)\left(24.47 \frac{\mathrm{J}}{\mathrm{mol} * K}\right)(1,773-1,174) K(20 \% \text { unreacted }) \\
& =5.03 E 10 \frac{\mathrm{J}}{\text { day }} \\
& \left(5.03 E 10 \frac{\mathrm{J}}{\text { day }}\right)\left(\frac{h r}{3600 \mathrm{~s}}\right)\left(\frac{G W}{10^{9} * \frac{J}{S}}\right)=0.014 \frac{G W h r}{d a y} \\
& \left(0.014 \frac{G W h r}{\text { day }}\right)\left(365 \frac{\text { day }}{y r}\right)=\mathbf{5} \frac{\boldsymbol{G W h r}}{\boldsymbol{y r}}
\end{aligned}
$$

Ar sensible heat recovered:

$\left(8.25 E 7 \frac{\mathrm{mol} \mathrm{Mn2O3}}{\text { day }}\right)\left(\frac{3 \text { molAr }}{1 m o l M n 203}\right)\left(20.786 \frac{\mathrm{J}}{\mathrm{mol} * K}\right)(1,773-1,174) \mathrm{K}=6.16 E 11 \frac{\mathrm{J}}{\mathrm{day}}$

$\left(6.16 E 11 \frac{J}{d a y}\right)\left(\frac{h r}{3600 s}\right)\left(\frac{G W}{10^{9} * \frac{J}{S}}\right)=0.17 \frac{G W h r}{d a y}$

$\left(0.17 \frac{G W h r}{d a y}\right)\left(365 \frac{d a y}{y r}\right)=\mathbf{6 2} \frac{\boldsymbol{G W h r}}{\boldsymbol{y r}}$

$\mathrm{MnO}$ sensible heat recovered:

$\left(8.25 E 7 \frac{\mathrm{mol} \mathrm{Mn2O3}}{\text { day }}\right)\left(\frac{2 \mathrm{molMnO}}{1 \mathrm{molMn} 203}\right)\left(58.496 \frac{\mathrm{J}}{\mathrm{mol} * K}\right)(1,773$

$$
-1,174) K(80 \% \text { conversion })=9.25 E 11 \frac{\mathrm{J}}{\mathrm{day}}
$$




$$
\begin{aligned}
& \left(9.25 E 11 \frac{J}{d a y}\right)\left(\frac{h r}{3600 s}\right)\left(\frac{G W}{10^{9} * \frac{J}{S}}\right)=0.26 \frac{G W h r}{d a y} \\
& \left(0.26 \frac{G W h r}{\text { day }}\right)\left(365 \frac{\text { day }}{y r}\right)=\mathbf{9 4} \frac{\boldsymbol{G W h} \boldsymbol{r}}{\boldsymbol{y} \boldsymbol{r}}
\end{aligned}
$$

O2 sensible heat recovered:

$$
\begin{aligned}
& \left(8.25 E 7 \frac{\text { mol Mn } 203}{\text { day }}\right)\left(\frac{\frac{1}{2} \text { molo } 2}{1 \text { molMn } 203}\right)\left(37.329 \frac{J}{m o l * K}\right)(1,773 \\
& -1,174) K(80 \% \text { conversion })=1.48 E 11 \frac{J}{d a y} \\
& \left(1.48 E 11 \frac{J}{d a y}\right)\left(\frac{h r}{3600 s}\right)\left(\frac{G W}{10^{9} * \frac{J}{S}}\right)=0.041 \frac{G W h r}{d a y} \\
& \left(0.041 \frac{G W h r}{d a y}\right)\left(365 \frac{\text { day }}{y r}\right)=\mathbf{1 5} \frac{\boldsymbol{G W h r}}{\boldsymbol{y} \boldsymbol{r}}
\end{aligned}
$$

\section{Total Sensible Heat Recovered}

$$
(139+5+62+94+15) \frac{G W h r}{y r}=\mathbf{3 1 5} \frac{\boldsymbol{G W h} \boldsymbol{r}}{\boldsymbol{y} \boldsymbol{r}}
$$

Sensible heat required for feed preheat:

$\mathrm{Mn} 2 \mathrm{O} 3$ sensible heat required:

$$
\begin{aligned}
& \left(8.25 E 7 \frac{\mathrm{mol} \mathrm{Mn} 203}{d a y}\right)\left(138.606 \frac{\mathrm{J}}{\mathrm{mol} * K}\right)(1,164-1,000) K=1.88 E 12 \frac{\mathrm{J}}{\text { day }} \\
& \left(1.88 E 12 \frac{\mathrm{J}}{\text { day }}\right)\left(\frac{\mathrm{hr}}{3600 \mathrm{~s}}\right)\left(\frac{G W}{10^{9} * \frac{J}{S}}\right)=0.52 \frac{G W h r}{\text { day }} \\
& \left(0.52 \frac{G W h r}{\text { day }}\right)\left(365 \frac{\text { day }}{y r}\right)=\mathbf{1 9 0} \frac{\boldsymbol{G W h r}}{\boldsymbol{y r}}
\end{aligned}
$$

$\mathrm{ZnO}$ sensible heat required:

$$
\begin{gathered}
\left(8.25 E 7 \frac{\mathrm{mol} \mathrm{Mn} 203}{\text { day }}\right)\left(\frac{1 \mathrm{molZnO}}{1 \mathrm{molMn} 203}\right)\left(24.47 \frac{\mathrm{J}}{\mathrm{mol} * \mathrm{~K}}\right)(1,164-1,000) \mathrm{K} \\
=3.45 E 11 \frac{\mathrm{J}}{\mathrm{day}}
\end{gathered}
$$




$$
\begin{aligned}
& \left(3.45 E 11 \frac{J}{d a y}\right)\left(\frac{h r}{3600 s}\right)\left(\frac{G W}{10^{9} * \frac{J}{S}}\right)=0.10 \frac{G W h r}{d a y} \\
& \left(0.10 \frac{G W h r}{\text { day }}\right)\left(365 \frac{\text { day }}{y r}\right)=\mathbf{3 5} \frac{\boldsymbol{G W h} \boldsymbol{r}}{\boldsymbol{y r}}
\end{aligned}
$$

Ar sensible heat required:

$$
\begin{aligned}
& \left(8.25 E 7 \frac{\mathrm{mol} \mathrm{Mn} 2 \mathrm{O} 3}{\text { day }}\right)\left(\frac{3 \mathrm{molAr}}{1 \mathrm{molMn} 2 \mathrm{O3}}\right)\left(20.786 \frac{\mathrm{J}}{\mathrm{mol} * \mathrm{~K}}\right)(1,164-1,000) \mathrm{K} \\
& =8.45 E 11 \frac{\mathrm{J}}{\mathrm{day}} \\
& \left(8.45 E 11 \frac{J}{d a y}\right)\left(\frac{h r}{3600 s}\right)\left(\frac{G W}{10^{9} * \frac{J}{S}}\right)=0.23 \frac{G W h r}{d a y} \\
& \left(0.23 \frac{G W h r}{d a y}\right)\left(365 \frac{d a y}{y r}\right)=\mathbf{8 6} \frac{\boldsymbol{G W h} \boldsymbol{r}}{\boldsymbol{y r}}
\end{aligned}
$$

Total Solar Heat Input

$(190+35+86) \frac{G W h r}{y r}=\mathbf{3 1 1} \frac{\boldsymbol{G W h} \boldsymbol{r}}{\boldsymbol{y} \boldsymbol{r}}$ 


\section{Efficiency}

\section{A. $\mathrm{H}_{2}$ Energy Production}

The lower heating value (LHV) of hydrogen is $120,000 \mathrm{~kJ} / \mathrm{kg}$. The solar plant produces $133,000 \mathrm{~kg} /$ day running 8 hours per day while the chemical plant runs 24 hours per day with an operating efficiency of $75 \%$. Therefore, the total plant output is $99,750 \mathrm{~kg} /$ day hydrogen.

$$
\begin{aligned}
& \left(99,750 \frac{\mathrm{kg} \mathrm{H} 2}{\text { day }}\right)\left(120,000 \frac{\mathrm{kJ}}{\mathrm{kg}}\right)\left(1,000 \frac{\mathrm{J}}{\mathrm{kJ}}\right)=1.2 E 13 \frac{\mathrm{J}}{\text { day }} \\
& \left(1.2 E 13 \frac{\mathrm{J}}{\text { day }}\right)\left(\frac{\mathrm{hr}}{3600 \mathrm{~s}}\right)\left(\frac{\mathrm{GW}}{10^{9} * \frac{J}{s}}\right)=3.33 \frac{G W h r}{\text { day }} \\
& \left(3.33 \frac{G W h r}{\text { day }}\right)\left(365 \frac{\text { day }}{\mathrm{yr}}\right)=\mathbf{1}, \mathbf{2 1 4} \frac{\boldsymbol{G W h r}}{\boldsymbol{y r}}
\end{aligned}
$$

\section{B. Electricity Consumption}

Solar field consumes 4,271 kWhr per 8 hour day, the water pumps use 119,318 kWhr per 24 hour day, and the compression system consumes 194,688 kWhr per 24 hour day.

$$
(4,271+119,318+194,688) \frac{k W h r}{d a y}\left(\frac{G W}{10^{6} * k W}\right)\left(365 \frac{d a y}{y r}\right)=\mathbf{1 1 6} \frac{\boldsymbol{G W h} \boldsymbol{y}}{\boldsymbol{y r}}
$$

\section{Solar Field Efficiency}

$40.2 \%$ based on the Soltrace solar field design program by Allan Lewandowski.

\section{Thermal Efficiency}

$\eta_{\text {Thermal }}=\frac{H_{2, L H V}+e_{\text {produced }}^{-}}{\text {Solar }+e_{\text {consumed }}^{-}}=\frac{1,214}{2,602+116}=\mathbf{4 4 . 6} \%$

\section{E. Process Efficiency}

$\eta_{\text {Process }}=\eta_{\text {Solar }} * \eta_{\text {Thermal }}=0.402 * 0.446=17.9 \%$

\section{F. STCH Efficiency}

$$
\eta_{\text {STCH }}=\frac{H_{2, L H V}}{\text { Solar } / \eta_{\text {Field }}}=\frac{1,214}{\frac{2,602}{0.402}+\frac{116}{0.400}}=\mathbf{1 7 . 9} \%
$$




\section{Economic Analysis}

\section{A. DOE EERE Technical Targets}

All cases are evaluated for the years 2015 and 2025 according to Sargent and Lundy's tower cost as well as the EERE heliostat costs and hydrogen selling price goals. All capital item costs are based on equipment pricing in 2007.

2015: Heliostats are $\$ 126.50 / \mathrm{m}^{2}$ installed and the secondary concentrators are $\$ 1,265 / \mathrm{m}^{2}$ installed. This is assuming that secondary concentrators cost $10 \mathrm{X}$ the price of a heliostat. Hydrogen will be delivered at 300 psig.

2025: Heliostats are $\$ 90 / \mathrm{m}^{2}$ installed and the secondary concentrators are $\$ 900 / \mathrm{m}^{2}$ installed. This is assuming that secondary concentrators cost $10 \mathrm{X}$ the price of a heliostat. Hydrogen will be delivered at 300 psig.

In all cases, the towers cost $\left(\$ 710,000+20.97 * \mathbf{h}^{2.392}\right) * \mathbf{1 . 1 2}$ where $\mathrm{h}$ is the tower height in meters. (Inflation has been taken into account.) The site preparation cost is $\$ \mathbf{8} . \mathbf{5 E 6} * \frac{\text { Field Area }\left(\mathrm{m}^{2}\right)}{2.67 \mathrm{EG}}$. The number of chemical plant staff required is equal to $\left(6.20+31.7 * p^{2}+0.23 * N\right)^{0.5}$ where $P$ is the number of processing steps involving handling of particulate solids and $\mathrm{N}$ is the number of non-particulate processing steps generally the total pieces of equipment. 0.016 staff will be required for the solar field per $100 \mathrm{~m}^{2}$ of the solar field.

\section{B. H2A Operating Assumptions}

\begin{tabular}{|ll|}
\hline \multicolumn{2}{|c|}{ Capital Costs } \\
\hline Engineering \& Design & $17.7 \% \mathrm{~T}_{\mathrm{Cl}, \text { Solar }}$ \\
\hline \multirow{2}{*}{ Project Contingency } & $16.8 \% \mathrm{~T}_{\mathrm{Cl}, \text { Solar }}$ \\
& $18 \% \mathrm{~T}_{\mathrm{Cl}, \text { Chemical }}$ \\
\hline Up-Front Permitting Costs & $3 \% \mathrm{~T}_{\mathrm{Cl}}$ \\
\hline Cost of land per acre & $\$ 2,024$ \\
\hline
\end{tabular}

Variable Operating Costs

Total Unplanned Replacement Capital Cost Factor per year $\quad 0.05 \% \mathrm{~T}_{\mathrm{Cl}}$ 


\begin{tabular}{|ll|}
\hline \multicolumn{2}{|c|}{ Financial Input Values } \\
\hline Length of Construction Period & $3 \mathrm{yrs}$ \\
\hline \% of Capital Spent in 1st Year of Construction & $10 \%$ \\
\hline \% of Capital Spent in 2nd Year of Construction & $25 \%$ \\
\hline \% of Capital Spent in 3rd Year of Construction & $65 \%$ \\
\hline Start-up Time & $0.5 \mathrm{yr}$ \\
\hline Plant life & $40 \mathrm{yrs}$ \\
\hline Analysis period & $40 \mathrm{yrs}$ \\
\hline Depreciation Schedule Length & $20 \mathrm{yrs}$ \\
\hline Depreciation Type & $\mathrm{MACRS}$ \\
\hline \% Equity Financing & $100 \%$ \\
\hline$\%$ of Fixed Operating Costs During Start-up & $100 \%$ \\
\hline$\%$ of Revenues During Start-up & $50 \%$ \\
\hline$\%$ of Variable Operating Costs During Start-up & $75 \%$ \\
\hline Decommissioning costs & $10 \%$ \\
\hline Salvage value & $10 \% \mathrm{~T}_{\mathrm{Cl}}$ \\
\hline Inflation rate & $1.9 \%$ \\
\hline After-tax Real IRR & $10 \%$ \\
\hline State Taxes & $6 \%$ \\
\hline Federal Taxes & $35 \%$ \\
\hline Total Tax Rate & $38.9 \%$ \\
\hline Working Capital & $15 \%$ \\
\hline
\end{tabular}

\begin{tabular}{|ll|}
\hline \multicolumn{2}{|c|}{ Fixed Operating Costs } \\
\hline $\begin{array}{l}\text { Total FTE Plant Staff } \\
\text { Solar Operators at } \$ 28 / \mathrm{hr} \\
\text { Plant Operators at } \$ 50 / \mathrm{hr}\end{array}$ \\
\hline G\&A Rate & $20 \%$ \\
\hline Property Taxes and Insurance & $1 \% \mathrm{~T}_{\mathrm{Cl}, \text { Solar }}$ \\
\hline \multirow{2}{*}{ Material costs for maintenance and repairs } & $2 \% \mathrm{~T}_{\mathrm{Cl}, \text { Chemical }}$ \\
\hline
\end{tabular}


C. 2007 Chemical Engineering Plant Cost Index

\begin{tabular}{|ll|}
\hline CE Index & 525.4 \\
\hline Equipment & 624.4 \\
Heat Exchangers \& Tanks & 592.1 \\
Process Machinery & 598.3 \\
Pipe, Valves, \& Fittings & 733.6 \\
Process Instruments & 425.2 \\
Pumps \& Compressors & 831.2 \\
Electrical Equipment & 430.5 \\
Structural Supports & 662.6 \\
Buildings & 476.8 \\
\hline
\end{tabular}

D. Solar Field Specifications \& Capital Equipment

\begin{tabular}{|c|c|c|c|c|}
\hline \multicolumn{5}{|c|}{ Solar Field Design } \\
\hline & & Chemical Plant Staff & & 56 \\
\hline & & Solar Staff & & 38 \\
\hline & & Site Preparation & $\$$ & $7,642,982$ \\
\hline \multirow{3}{*}{2015} & $\$ 127$ & Heliostats & $\$$ & $303,700,647$ \\
\hline & $\$ 1,265$ & Secondary Concentrators & $\$$ & $3,840,976$ \\
\hline & & Towers & $\$$ & $73,794,273$ \\
\hline \multirow{3}{*}{2025} & 90 & Heliostats & $\$$ & $216,071,607$ \\
\hline & $\$ 900$ & Secondary Concentrators & $\$$ & $2,732,710$ \\
\hline & & Towers & $\$$ & $73,794,273$ \\
\hline
\end{tabular}

E. H2A Results

\begin{tabular}{|c|c|c|}
\hline & H2 selling Price $(\$ / \mathrm{kg})$ & DOE STCH Target \\
\hline 2015 & $\$ 6.48$ & $\$ 6.00$ \\
\hline 2025 & $\$ 6.09$ & $\$ 4.00$ \\
\hline
\end{tabular}




\section{Results \& Conclusions}

This cycle has uncovered several challenges. First, the allowable hydrogen selling price in 2015 is $\$ 6.48 / \mathrm{kg}$ and $\$ 6.09 / \mathrm{kg}$ in 2025 . While the DOE selling price targets are $\$ 6.00 / \mathrm{kg}$ in 2015 and $\$ 4.00 / \mathrm{kg}$ in 2025 . Hence, this cycle does not achieve either target in its present form. The pie charts below show that the cost of capital equipment required in this cycle accounts for $60-66 \%$ of the total capital investment.
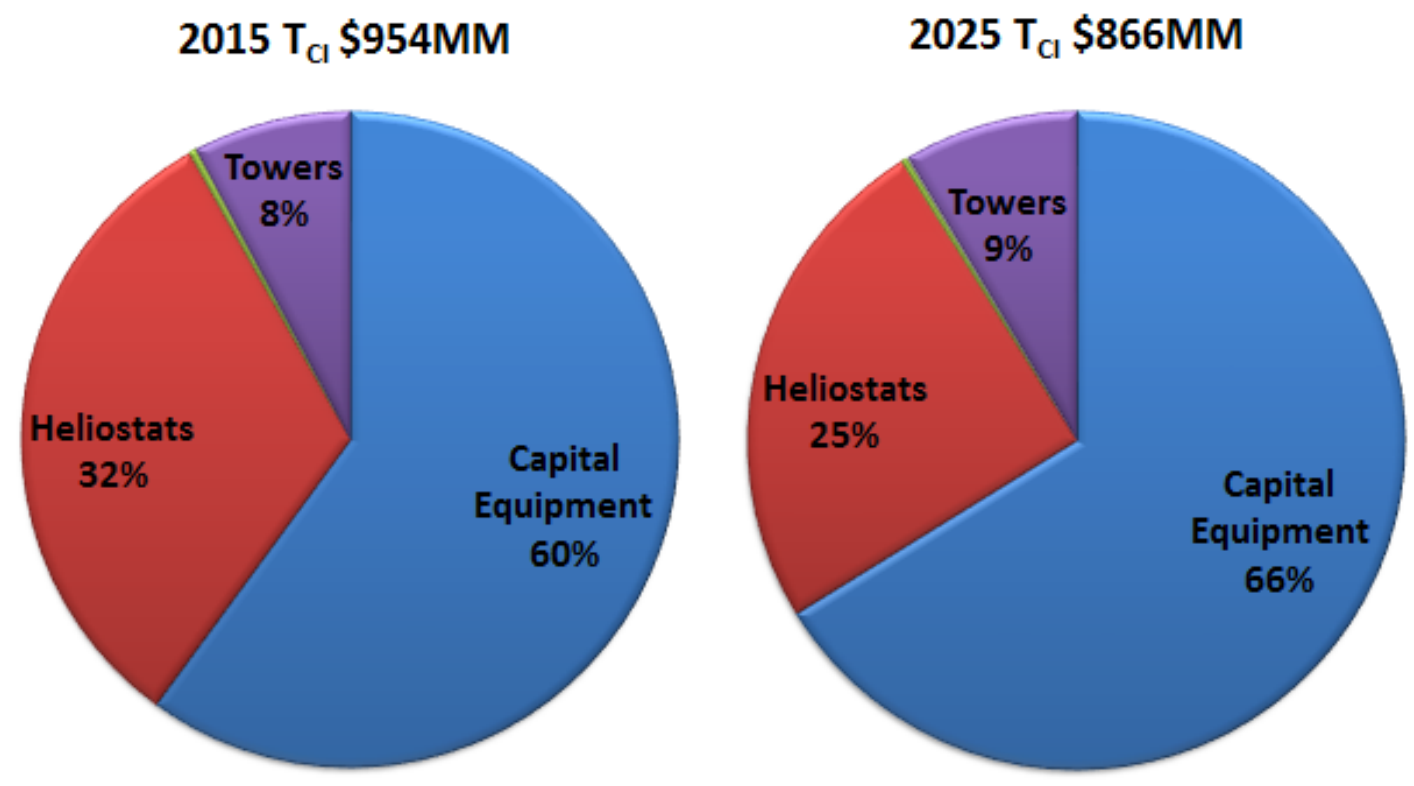

The solarthermal reaction step appears feasible. However, there is an issue with this cycle relative to the recovery of sodium hydroxide from water. A lot of energy is required for this step. The process variation presented here by adding $\mathrm{ZnO}$ is still a challenge since it is still difficult to completely remove sodium hydroxide from manganese in the second reaction. Since sodium hydroxide is not completely removed in this step, approximately $10 \%$ is recycled with manganese to the solar reaction.

Finally, this analysis relies on the availability of an oxygen transport membrane (OTM) to separate oxygen from argon used in the solar reaction. This separation allows argon to be recycled, thus reducing the variable operating cost associated with argon use. OTMs are currently in the research phase and, therefore, not immediately available on the market.

A key issue is the ability to recover sodium hydroxide at low cost from an aqueous stream. The development of such a process will move the sodium manganese process closer to a viable process for producing renewable $\mathrm{H}_{2}$. 